\title{
Peran orang tua dan guru dalam mengembangkan moral peserta didik sekolah dasar di era revolusi industri 4.0
}

\author{
Marsen $\mathbf{C}^{\left.{ }^{*}\right)}$, Neviyarni $\mathbf{S}^{1}$, Irda Murni ${ }^{1}$ \\ Universitas Negeri Padang
}

\begin{tabular}{l} 
Article Info \\
\hline Article history: \\
Received April $20^{\text {th }}, 2021$ \\
Revised May $18^{\text {th }}, 2021$ \\
Accepted Jun $25^{\text {th }}, 2021$ \\
\hline
\end{tabular}

\section{Keyword:}

Moral

Peserta didik

Sekolah dasar

\begin{abstract}
Moral merupakan aspek yang sangat penting dalam kehidupan bermasyarakat yang juga bisa didapat melalui proses pendidikan. Kenyataannya saat ini moral peserta didik sekolah dasar mengalami yang namanya degradasi moral yaitu lunturnya nilai moral dalam kehidupan bermasyarakat. Oleh karena itu diperlukan peran dari orang tua dan guru untuk mengembangkan dan meningkatkan kembali moral peserta didik tersebut. Pada artikel ini akan dipaparkan mengenai peran orang tua dan guru dalam mengembangkan moral peserta didik sekolah dasar di era revolusi industri 4.0. Tujuannya adalah untuk mengetahui peran orang tua dan guru dalam mengembangkan moral peserta didik SD. Metode penelitian yang digunakan dalam penelitian ini adalah dengan menggunakan metode study literatur research atau studi kepustakaan dengan mengkaji berbagai jurnal yang memiliki kaitan atau hubungan dengan peran orangtua dan guru dalam mengembangkan moral peserta didik sekolah dasar di era revolusi industri 4.0. Berdasarkan hasil penelitian peran guru dan orangtua dalam mengembangkan karakter peserta didik sekolah dasar pada masa pandemic adalah teladan yang ditiru oleh anak dalam bersikap dan berkepribadian, mengarahkan pembentukan moral dan karakter, pembiasaan hal- hal positif, penyisipan nilai moral dalam pembelajaran. Selain itu perlu dilakukan control dan bimbingan, pengawasan, evaluasi dan tindak lanjut dari perilaku moral anak tersebut.
\end{abstract}

(C) 2021 The Authors. Published by IICET.

This is an open access article under the CC BY-NC-SA license

(https://creativecommons.org/licenses/by-nc-sa/4.0)

Corresponding Author:

Marsen C,

Universitas Negeri Padang

Email: marsen.c.mc@gmail.com

\section{Pendahuluan}

Dalam kehidupan bermasyarakat moral merupakan suatu aspek yang penting yang diperoleh melalui proses pendidikan. Kenyataannya saat ini moral peserta didik sekolah dasar mengalami yang namanya degradasi moral yaitu lunturnya nilai moral dalam kehidupan bermasyarakat. Oleh karena itu diperlukan peran dari orangtua dan guru untuk mengembangkan dan meningkatkan kembali moral peserta didik tersebut. Pada artikel ini akan dipaparkan mengenai peran orangtua dan guru dalam mengembangkan moral peserta didik sekolah dasar di era revolusi industri 4.0. Pada tulisan ini karena masa sekarang seiring perkembangan zaman sudad terjadi kemorosotan nilai anak sehingga perlu kita ketahui peran orang tua dan guru dalam mengembangkan kembali nilai moral tersebut. Kajian ini focus pada peran orang tua dan guru dalam mengembangkan nilai moral anak. 


\section{Metode}

Penelitian ini menggunakan metode study literatur research atau studi kepustakaan dengan mengkaji berbagai jurnal yang memiliki kaitan atau hubungan dengan peran orangtua dan guru dalam mengembangkan moral peserta didik sekolah dasar di era revolusi industri 4.0. Metode studi kepustakaan menurut Sugiyono (2018) adalah suatu metode yang mana mengumpulkan kajian teori dan referensi yang bersumber dari literaturliteratur ilmiah. Jadi dalam metode studi kepustakaan ini peneliti tidak perlu turun ke lapangan untuk mencari informasi, melainkan cukup dengan mengkaji serta menyimpulkan berdasarkan sumber yang didapat dari berbagai literatur. Penelitian ini bertujuan untuk melihat peranan orang tua maupun guru dalam upaya mengembangkan moral peserta didik sekolah dasar di era revolusi industri 4.0

\section{Pembahasan}

Hasil dari artikel ini diperoleh dengan cara mencari, meninjau dan menelaah jurnal- jurnal serta referensi yang terkait dengan peran orangtua dan guru dalam mengembangkan moral peserta didik sekolah dasar di era revolusi industri 4.0. Orang tua maupun guru merupakan aktor yang ditiru oleh anak dalam bersikap dan berkepribadian. Oleh sebab itu peranan orang tua dan guru sangat penting dalam mengembangkan moral peserta didik agar ditiru sebagaimana yang diharapkan.

Menurut (Ramdan \& Fauziah, 2019) untuk mengembangkan nilai karakter/ moral peserta didik, guru dan orang tua dapat melakukan hal- hal sebagai berikut: Membimbing pembentukan karakter anak di rumah, Membangun komunikasi yang baik dengan anak, Memberikan teladan berperilaku seperti: jujur, disiplin, sopan santun, tanggung jawab, toleransi serta peduli kepada orang lain, pengembangan pendidikan karakter.

Kolaborasi antara sekolah, keluarga dan masyarakat penting agar menciptakan generasi yang bermoral dan berakhlak mulia (Hendayani, 2019). Dalam penanaman moral bagi peserta didik sd bisa dimulai dengan pembiasaan terhadap hal positif yang kemudian diterapkan dalam proses pembelajaran, setelah kegiatan pembelajaran dilakukan kemudian dilanjutkan ke dalam kegiatan ekstrakurikuler. Dengan begitu, pembiasaan terhadap hal positif pada lingkungan sekitar mampu menanamkan moral secara langsung kepada peserta didik. Jadi intinya penanaman moral ditanamkan dengan penyisipan saat kegiatan pembelajaran di sekolah (Amelia, 2018)

Pembiasaan dan contoh langsung yang diberikan oleh orangtua, guru maupun orang- orang di sekitar merupakan hal yang sangat penting dalam upaya pembinaan moral siswa. Karakter yang ditanamkan dalam pembinaan moral siswa tidak bertentangan berdasarkan nilai moral yang berlaku. Apabila suatu perbuatan dilakukan secara berulang tindakan maka akan menjadi sebuah kebiasaan dan menjadi kepribadian dalam diri siswa. Oleh sebab itu, siswa yang mempunyai kepribadian kuat dapat mengatasi permasalahan permasalahan yang timbul dalam kehidupannya. Perkembangan arus globalisasi yang saat ini bukanlah satusatunya penyebab manusia jauh dari nilai moral yang baik, sehingga siswa yang merupakan calon penerus generasi penerus bangsa harus memiliki karakter yang kuat (Rifa, 2017).

Guru dapat menanamkan moral kepada siswa melalui penyisipan 10 nilai moral yaitu nilai religius, kejujuran, keadilan, kemandirian, social, tanggung jawab, daya juang, nilai gender, nilai demokrasi, dan nilai penghargaan terhadap lingkungan (Aini et al., 2016).

Dalam rangka menanamkan nilai moral kepada anak, maka guru dan orangtua dapat berkolaborasi dalam menerapkan hal- hal sebagai berikut yaitu melaksanakan aturan, mengatasi perilaku yang menyimpang, mengatakan "Tidak" dengan tegas jika anak melakukan kesalahan, membuat konsekuensi, konsisten, memiliki empati, membuat kesepakatan, menawarkan pilihan lain, serta memberikan pujian (U. Hasanah, 2018)

Pelaksanaan pendidikan moral membutuhkan kerjasama dari berbagai pihak, yaitu: orang tua berperan penting di rumah dan guru berperan penting di sekolah. Orang tua merupakan guru pertama bagi anak. Tingkah laku maupun perbuatan orang tua akan ditiru oleh anak sehingga orang tua harus menjadi teladan yang baik dalam membentuk moral anak. Setelah orangtua, guru pun merupakan panutan bagi anak. Dalam proses pembelajaran guru hendaklah menyisipkan unsur-unsur moral ke dalam pembelajaran (Khaironi, 2017).

Dalam pengembangan moral ada beberapa prinsip yang perlu diperhatikan yaitu, berpusat pada perkembangan anak, kebutuhan anak, belajar sambil bermain, lingkungan yang nyaman, , pembelajaran terpadu, terdapat pengembangan kecakapan hidup, memanfaatkan media dan sumber belajar edukatif, dilaksanakan bertahap, PAIKEM, memanfaatkan IT. 
Cara penanaman moral yang dapat dilakukan guru adalah melalui bercerita, karyawisata, bernyanyi serta lewat syair/ sajak. Salah satu tujuan dalam pendidikan adalah membentuk dan mengembangkan moral peserta didik. Orang tua dan guru berperan penting mengarahkan anak untuk berperilaku sesuai norma moral mengatur kehidupan bermasyarakat (E. Hasanah, 2019).

Pendidikan dalam keluarga adalah pilar utama dalam pembentukan karakter seorang anak. Proses pendidikan pertama kali dimulai dari orang tua. Orang tua merupakan sumber pendidikan dan masyarakat pertama dalam keluarga yang berperan penting dalam pembentukan karakter anak. Sehingga jika ingin membentuk moral dan karakter anak yang berkualitas maka orang tua itu harus memiliki karakter yang berkualitas terlebih dahulu demi tercapainya harapan untuk pendidikan moral anak ini dan mendapat hasil yang memuaskan.

Perilaku yang bisa diterapkan oleh orang tua dalam membentuk nilai karakter dan moral kepada anak adalah mengikutsertakan anak dalam pekerjaan dirumah, membiasakan anak untuk membuang sampah pada tempatnya dan tidak meludah di sembarangan tempat serta menegur anak jika melakukan perbuatan yang tidak wajar (Subianto, 2013)

Pembentukan moral anak sangat dipengaruhi oleh faktor lingkungan, karakter, perbuatan dan perkataan orangtua. Banyak anak yang memiliki kepercayaan diri rendah atau kepercayaan diri yang berlebihan itu dapat terjadi karena kesalahan pola asuh yang tak baik oleh orangtuanya. Pola asuh keluarga merupakan faktor utama dari berbagai norma dan etika yang berlaku dalam lingkungan bermasyarakat, dan melalui hal itu akan dapat meneruskan budaya yang ada di lingkungan sekitar kepada anak (Hasyim, 2016)

Pembentukan karakter tidak terlepas dari lingkungan keluarga, sekolah dan lingkungan yang berada di sekitar individu. Keluarga merupakan pondasi dasar yang menjadi faktor penentu akan seperti apa dan bagaimana karakter seorang anak. Apabila keluarga telah menjalankan perannya dengan baik, maka akan terbentuk anak yang memiliki karakter dan moral yang baik sehingga menghasilkan anak yang berkualitas.

Tidak hanya orangtua yang berperan, sekolah dan guru juga berperan penting dalam pembentukan moral anak. Adapun contoh perilaku yang dapat diterapkan diantaranya yaitu, membudayakan salam, senyum, sapa, sopan dan santun pada setiap warga sekolah, membudayakan berbicara dengan bahasa yang lembut, mengarahkan anak untuk duduk selalu dengan sopan, membiasakan siswa untuk tidak berjalan saat makan.

Upaya pembentukan karakter anak di sekolah dapat dilakukan dengan adanya sosialisasi dan pembiasaan lingkungan sekolah untuk menegakkan nilai-nilai akhlak dan moral yang benar melalui teladan. Setiap guru dan tenaga kependidikan sekolah hendaknya menjadi contoh nyata bagi setiap peserta didik. Dalam pengembangan dan penanaman nilai moral kepada anak perlu dilakukan pengamatan dan pembimbingan, pengawasan, evaluasi dan tindak lanjut. Tindak lanjut merupakan upaya memperbaiki atau mempertahankan karakter yang ada pada peserta didik setelah dilakukannya evaluasi (Amaruddin et al., 2020)

Penanaman nilai moral juga dapat dilakukan dengan cara memberikan contoh karakter tokoh yang ada dalam cerita. Penanaman nilai karakter dan moral anak diberikan melalui contoh-contoh nyata dan bisa ditiru oleh anak dalam kehidupan (Ramdhani et al., 2019)

Peran guru tak hanya menanamkan nilai namun juga memberikan contoh dalam pembentukan moral anak, sehingga moralitas siswa dapat bekembang menjadi kesadaran moral. Guru sebagai pusat perhatian perlu memberikan contoh teladan yang baik agar moral siswanya juga baik. Dengan adanya kesadaran moral maka para siswa akan berhati-hati dalam bersikap dan berperilaku. Siswa dapat membedakan perilaku yang pantas dan tidak pantas sesuai norma yang berlaku di masyarakat sekitar (Wijayanti, 2015)

Guru juga dapat melakukan penanaman nilai moral dengan mengaplikasikan pada kegiatan belajar contohnya pada materi pantun. Dalam pembelajaran perlu dilakukan penekanan, pemahaman, pengulangan, refleksi terhadap nilai moral yang diaplikasikan pada pembelajaran tersebut (Camalia et al., 2016)

\section{Simpulan}

Jadi berdasarkan hasil penelitian dapat disimpulkan peran guru dan orangtua dalam mengembangkan karakter peserta didik sekolah dasar pada masa pandemic adalah role model/ teladan yang ditiru oleh anak dalam bersikap dan berkepribadian, mengarahkan pembentukan moral dan karakter, pembiasaan hal- hal positif, penyisipan nilai moral dalam pembelajaran, menanamkan nilai moral pada anak lewat bercerita/ mendongeng, melakukan pendekatan "modelling" atau "exemplary" atau "uswah hasanah" yaitu mensosialisasikan dan membudayakan lingkungan sekolah dalam menegakkan nilai-nilai akhlak dan moral yang benar melalui contoh dan teladan yang baik. Selain itu dalam pengembangan dan penanaman moral 
pada peserta didik perlu dilakukan control dan bimbingan, pengawasan, evaluasi dan tindak lanjut dari perilaku moral anak tersebut.

\section{Referensi}

Aini, N., Ruslan, R., \& Ely, R. (2016). Penanaman nilai-nilai moral pada siswa di sd negeri lampeuneurut. Jurnal Ilmiah Mahasiswa Pendidikan Guru Sekolah Dasar, 1(1).

Amaruddin, H., Atmaja, H. T., \& Khafid, M. (2020). Peran Keluarga dan Media Sosial dalam Pembentukan Karakter Santun Siswa di Sekolah Dasar. Jurnal Pendidikan Karakter, 10(1).

Amelia, D. J. (2018). Penanaman Pendidikan Karakter Melalui Multiple Intelligences di SD Muhammadiyah 9 Kota Malang. Didaktis: Jurnal Pendidikan Dan Ilmu Pengetahuan, 18(1).

Camalia, D., Ikhwan, W. K., \& Mujtahidin, M. (2016). Pendidikan Nilai-Moral Melalui Pembelajaran Pantun pada Siswa Sekolah Dasar. Pamator Journal, 9(2).

Hasanah, E. (2019). Perkembangan Moral Siswa Sekolah Dasar Berdasarkan Teori Kohlberg. JIPSINDO, Jurnal Pendidikan Ilmu Pengetahuan Sosial Indonesia, 6(2), 131-145.

Hasanah, U. (2018). Metode Pengembangan Moral Dan Disiplin Bagi Anak Usia Dini. METODE, 2(1).

Hasyim, R. (2016). Peranan Orang Tua Dalam Pembentukan Moral Siswa Di Sd Negeri Tabam Kecamatan Kota Ternate Utara. PedagogiK, 4(1).

Hendayani, M. (2019). Problematika Pengembangan Karakter Peserta Didik Di Era 4.0. Jurnal Penelitian Pendidikan Islam, $[S L], 7(2), 183-198$.

Khaironi, M. (2017). Pendidikan Moral Pada Anak Usia Dini. Jurnal Golden Age, 1(01), 1-15.

Ramdan, A. Y., \& Fauziah, P. Y. (2019). Peran orang tua dan guru dalam mengembangkan nilai-nilai karakter anak usia sekolah dasar. Performance Evaluation, 9(2), 100-111. https://doi.org/10.25273/PE.V9I2.4501

Ramdhani, S., Yuliastri, N. A., Sari, S. D., \& Hasriah, S. (2019). Penanaman nilai-nilai karakter melalui kegiatan storytelling dengan menggunakan cerita rakyat Sasak pada anak usia dini. Jurnal Obsesi: Jurnal Pendidikan Anak Usia Dini, 3(1), 153-160.

Rifa, M. A. (2017). Strategi pengembangan kecerdasan moral siswa di sekolah berbasis islamic boarding school.

Subianto, J. (2013). Peran keluarga, sekolah, dan masyarakat dalam pembentukan karakter berkualitas. Edukasia: Jurnal Penelitian Pendidikan Islam, 8(2).

Wijayanti, D. (2015). Analisis Pengaruh Teori Kognitif Jean Piaget Terhadap Perkembangan Moral Siswa Sekolah Dasar Melalui Pembelajaran IPS. Trihayu, 1(2), 258991. 